\title{
Islamic Feminism in India: Indian Muslim Women Activists and the Reform of Muslim Personal Law ${ }^{1}$
}

\author{
SYLVIA VATUK
}

\author{
Department of Anthropology ( $\mathrm{m} / \mathrm{c}$ o2 7$)$, University of Illinois at Chicago, \\ Ioo7 West Harrison St., Chicago, IL 6o6o7 \\ E-mail:vatuk@uic.edu
}

\begin{abstract}
I describe here a nascent 'Islamic feminist' movement in India, dedicated to the goal of achieving gender equity under Muslim Personal Law. In justifying their demands, these women activists refer neither to the Indian Constitution nor to the universalistic human rights principles that guide secular feminists campaigning for passage of a gender-neutral uniform civil code of personal law, but rather to the authority of the Qur'an-which, they claim, grants Muslim women numerous rights that in practice are routinely denied them. They accuse the male 'ulama of foisting 'patriarchal' interpretations of the Qur'an on the unlettered Muslim

${ }^{1}$ I thank Filippo and Caroline Osella for giving me a reason to think more seriously and systematically about the movement I discuss here and for their careful reading and critiques of earlier drafts. Geraldine Forbes, Karen Leonard and Andrea Rugh have also provided valuable input. I am especially grateful to Yoginder Sikand for initially calling my attention to the phenomenon of Muslim women's rights activism in India. I am indebted to the following women who, at various times between 1998 and 2006, kindly made time in their busy schedules to allow me to observe their ongoing activities, talk about their ideas, their goals, their past and current activities and their future plans: Haseena Hashia, Sona Khan, Sughra Mehdi, Terry Rogers and Suraiya Tabassum in New Delhi, Nigar Ataulla and Hasnath Mansur in Bangalore, Flavia Agnes, Neelofar Akhtar, Farhat, Nasreen Fazalbhoy, Hasina Khan, Khatun Begum, Uzma Naheed, Naseem, Noorjehan Safia Niaz, and Yasmin in Mumbai, Jameela Nishat, Noorjahan Begum and Rehana Sultana in Hyderabad and Badr Sayeed in Chennai. Finally, I thank the following religious authorities for discussing their work and sharing their perspectives on women's rights and duties under MPL: Mohammed Abdul Rahim Qureshi, Secretary of the All-India Muslim Personal Law Board (AIMPLB), Muhammad Khwaja Sharif, Dean of the Department of Hadis at Ja'mia Nizamia and Qazis Anjam Arifi, Mir Muhammad Qadar Ali, and Najamuddin Husain Shah in Hyderabad; Qazi Salahuddin Muhammad Ayyub in Chennai; Qazi Muhammad Waliullah in Vanyambadi; and Syed Jalaluddin Umari, Vice-President of the Jama'at-i Islami Hind (JIH), and Qazi Maulana Kamil, presiding officer of the AIMPLB's dar-ul quzat, in New Delhi.
\end{abstract}


masses and assert their right to read the Qur'an for themselves and interpret it in a woman-friendly way. Their activities reflect an increasing 'fragmentation of religious authority' in the globalizing Muslim world, associated with the spread of mass education, new forms of media and transport and a mobile labour force, in which clerical claims to exclusive authoritative knowledge are being questioned by a wide variety of new voices, women's among them. Whether it can ultimately succeed is an open question but the movement is clearly having an impact, even on the clerical establishment itself, insofar as the legal issues it considers most pressing for women are concerned.

\section{Introduction}

In recent years, growing numbers of Muslim women in India have been publicly calling for reform of Muslim Personal Law (MPL), justifying their demands for gender equity with religious arguments, referring to the authority of the Qur'an rather than to the Indian Constitution or to the universalistic principles of human rights that have long guided Indian secular feminists in their campaigns for a genderneutral uniform civil code (UCG) of personal law. These women are part of a trend observable all over the Muslim world, in which 'a new breed of Muslim women scholar-activists' ${ }^{\text {'2 }}$ is seriously and critically studying the foundational texts of their religion. They are

challeng[ing] conventional histories and canonical texts... pointing to the openness of the Qur'an and Sunna to ijtihad... looking at the context in which the Qur'an was revealed... [and] applying this understanding to the present so as to question the ways in which Islamic knowledge has been produced. ${ }^{3}$

Scholars of the Middle East began to use the term 'Islamic feminism' in the 1990s for movements then gaining prominence in Egypt, Iran and elsewhere, in which women were attempting, 'through a rereading of the Qur'an and early Islamic history' to 'reclaim their religion... [and] undermine both Islamist patriarchal distortions and Western stereotypes of Islam as backward and terroristic'. ${ }^{4}$ While the

\footnotetext{
${ }^{2}$ Yoginder Sikand, 'The Muslim Personal Law Debate: Need to Listen to Alternative Voices', http://www.islaminterfaith.org (May 5, 2005), accessed May 7, 2005 .

${ }_{3}^{3}$ Miriam Cooke, Women Claim Islam: Creating Islamic Feminism Through Literature (New York: Routledge 2001), p. 62.

${ }^{4}$ Valentine M. Moghadam, Toward Gender Equality in the Arab/Middle East Region: Islam, Culture and Feminist Activism, HDR Office Occasional Paper (New York: UNDP 2004), p. 53 .
} 
goals of these Islamic feminists-to achieve greater gender equity under the law and in society more generally-are similar to those pursued by 'secular feminists', their understanding of the sources of male bias in Muslim societies and many of the remedies they propose to combat it are different.

Many scholars have questioned whether those whose aim is to get women their Qur'anic rights can be called 'feminists' at all and the related issue of whether an 'Islamic approach' to gender justice is in any way viable has aroused strenuous scholarly debate. ${ }^{5}$ Moghissi, for example, sees a real risk that if Iranian women are pushed into accepting an 'Islamic feminist' approach as 'the only "culturally suitable" or workable' one, any chances of achieving true gender equity will be foreclosed. ${ }^{6}$ Muslim women activists in India do not have to contend with the force of an authoritarian Islamic state. But their adversary, a well-entrenched and widely influential male religious establishment, is only slightly less intimidating. Insofar as they choose to confine themselves to 'changing MPL from within', rely on the Qur'an for guidance and side with the 'ulama in their rejection of state intervention, they risk having to scale back their aspirations for gender equity under the law.

Nair has a slightly different but related fear. 'It may be too early', she says, 'for feminists to take heart' from the growth of Islamic feminism in India, because blatant challenges to the authority of the ulama may have 'the unfortunate consequence of providing a rallying point for a new patriarchal unity', leading to renewed attempts to make women give priority to community solidarity over the pursuit of their own interests as women. I am somewhat more optimistic than Nair on this point. It seems unlikely to me that the women whose activities I will describe here will allow themselves to be distracted by religious identity-based appeals of this kind. This is especially true for those among them who are already more-or-less openly calling for taking

\footnotetext{
${ }^{5}$ For example, Moghadam, 'Islamic Feminism and its Discontents: Toward a Resolution of the Debate', Signs 27/4(2002), pp. 1135-1171; Haideh Moghissi, Feminism and Islamic Fundamentalism: The Limits of Post-Modern Analysis (Karachi: Oxford University Press, 1999); Margot Badran, Feminism Beyond East and West: New Gender Talk and Practice in Global Islam (New Delhi: Global Media Publications, 2007).

${ }^{6}$ Moghissi, Feminism, p. 10. Cf. Moghadam, 'Islamic Feminism'; Ziba Mir-Hosseini, Islam and Gender: The Religious Debate in Contemporary Iran (Princeton, NJ: Princeton University Press 1999).

${ }^{7}$ Janaki Nair, 'Doing it Their Way', The Telegraph (Calcutta), February 9, 2005 (http://india.indymedia.org/en/2005/02/210101.shtml, accessed October 14, 2005).
} 
the next step, working to get women their Islamic rights but preparing them to 'go beyond shari'at' to obtain those that the Qur'an does not provide. There is little sign that these women can be made to stop and reverse direction anytime soon.

Realistically speaking, there is, for a variety of political reasons, little prospect that either a UCG or any new legislation within MPL will be enacted in India in the foreseeable future. Under these circumstances, an 'Islamic feminist' approach holds considerable promise, at least in the short run, for improving the legal lot of Muslim women. The movement may make some concrete progress toward remedying the consistent failure of the religious authorities to implement those provisions of Islamic law that were originally designed to protect women but are widely ignored in practice today. More importantly, as these activists' voices become louder and more persistent, making the Muslim community_clerical and lay alike_increasingly aware of the issues and of the remedies they propose, some amount of change is inevitable. Clearly, an approach that merely seeks to obtain for women those rights provided them in the Qur'an will not lead to complete equality of the sexes. But it is nevertheless a promising beginning.

\section{An Islamic Feminist 'Movement'?}

Islamic feminist activism in India is not yet an organized 'social movement', in the strict sense of that term. It is being pursued by a rather amorphous assortment of individuals and groups, all engaged in avid discussion and debate about the negative impact of MPL on women but only loosely organized in terms of action. ${ }^{8}$ These women share similar goals - to spread awareness of 'the correct teachings of Islam' about women's rights (huquq-e-niswān) and find ways to help women gain practical access to them. And they employ similar arguments to justify their calls for legal reform.

\footnotetext{
${ }^{8}$ Margot Badran, for example, contends that in the Egyptian context it is inappropriate to speak of a 'feminist movement', because gender activism there 'is mainly pragmatic rather than political in the more highly-organised or selfconscious sense' ('Gender Activism: Feminists and Islamists in Egypt', in Valentine M. Moghadam (ed.), Identity Politics and Women: Cultural Reassertions and Feminisms in International Perspective (Boulder: Westview Press 1994), p. 203. Nadje Sadig Al-Ali, on the other hand, is prepared to define the term 'movement' more broadly (Secularism, Gender and the State in the Middle East: The Egyptian Women's Movement (Cambridge: Cambridge University Press, 2000), pp. 3-8.
} 
Though most work quite independently or in small groups, they are well aware of one another and even those living in distant places find or create periodic opportunities to meet and exchange ideas. Sometimes they join together, often in cooperation with sympathetic secular feminist organisations, to call a press conference, draw up and submit a petition or demonstrate publicly against some perceived threat-whether from the state or from orthodox religious forces-to Muslim women's welfare.

How many are involved in this nascent movement is impossible to gauge. There are a few prominent activists in each of the major cities and in certain other second-tier urban centres like Lucknow, Ahmedabad and Calicut. Some run small to medium-sized NGOs with associated staff and have a significant local 'grassroots' following. But, even if one includes the latter in the reckoning, they are far fewer than the numbers associated with 'women's wings' of Islamist reform organisations like the Tablighi Jama'at (TJ) or Jama'at-i Islami Hind (JIH).

\section{The All-India Muslim Women's Personal Law Board}

Two years ago, the formation of an All-India Muslim Women's Personal Law Board (AIMWPLB) drew national and even some international media attention. ${ }^{9}$ The organisation was conceived by a small group of prominent women who had gathered in Lucknow for a wedding. They cited as the motive for their action the failure of the mainly male All India Muslim Personal Law Board (AIMPLB) ${ }^{10}$ to seriously come to grips with women's concerns: 'Despite prattling about working for the rights of the women, the men-dominated boards took no account of the voice of women [italics mine]'. ${ }^{11}$ They assembled 35 women, representing the major sects and schools of Islamic jurisprudence and including a few Hindus. They got off to a good start

9 Tarannum Manjul, 'Four Law Boards: Will Muslim Women Find a "Masiha"?' (http://www.sawf.org/newedit/edit02072005/index.asp [February 7, 2005], accessed May 5,2005$)$.

${ }_{10}$ This self-appointed body was established in 1973 'to protect the Muslim Personal Law in India'. Its 201 members include many of the country's leading clerics, representing the major Islamic sects (http://www.aimplboard.org/index.html). It has no real authority to set legal policy for the Muslim community but is very vocal and exercises a great deal of public influence on matters related to MPL.

${ }^{11}$ Manjul, 'Four Law Boards'. 
toward the end of February 2005, convening a mahila adalat ('women's court'), at which 166 cases of unilateral divorce and 'atrocities related to dowry' were registered. The alleged offenders were summoned to appear 2 months later to answer the charges. ${ }^{12}$

The AIMWPLB was greeted by condemnation and derision from members of the AIMPLB, who denied its legitimacy and questioned the women's scholarly credentials and political motives. ${ }^{13}$ But, that body was already becoming increasingly sensitive to charges-from both within and outside of the community — of failing to address women's problems. It had begun to pay more attention to such issues at its annual meetings and in 2001 had organized a national conference to which it invited some of its more prominent female critics. In 2000 the Board was enlarged and the number of slots reserved for lady members' was increased. ${ }^{14}$ But women still represent only $12 \%$ of its membership. Even if they voted as a bloc they could not seriously influence the outcome of the Board's deliberations. Some observers complain that these women do little to promote women's causes in any case, either because they genuinely share the conservative outlook of the male majority or because

they are simply too scared to speak out against [the Board's] patently patriarchal biases... They fear that if they do they might be accused of dividing the community or challenging the authority of the mullahs. ${ }^{15}$

In all fairness, it should be noted that several of these women have taken strong pro-woman positions during the Board's deliberations in recent years. But so far they have little to show for their efforts. ${ }^{16}$

Neither the women behind the Lucknow initiative nor other women's rights activists are asking that MPL be abolished or

12 'Muslim women board registers 166 cases', The Hindu, February 27, 2005, http://www.hindu.com/2005/02/27/stories/2005022702101100.htm, accessed April $25,2006$.

13 'Muslim Women's Board is a Joke', The Muslim News, February 3, 2005, http://www.muslimnews.co.uk/news.php?article $=8786$, accessed October 14, 2005.

${ }_{14}$ Originally, 15 seats $(10 \%)$ were reserved for women: there are now 25 . One serves on the 41 member executive committee (All India Muslim Personal Law Board, 'Rules and Regulations', Constitution, [New Delhi: AIMPLB, 2003], pp. 7-8).

${ }^{15}$ Yoginder Sikand, 'Interview: Hasnath Mansur on Muslim Women and the AllIndia Muslim Personal Law Board', http://www.islaminterfaith.org (February 12, 2005), accessed March 8, 2005.

${ }^{16}$ For example, when a new nikahnāma ('marriage contract') was being drafted, Begum Naseem Iqtedar Ali, the sole woman on the Executive Committee, tried unsuccessfully to insert a provision for 'delegated divorce' (see below). See S. Anand et al., 'Muslim Personal Law: Amend, Amend, Amend!', Outlook India, July 19, 2004. 
secularized, nor do most of them favour passage of a UCG. By and large they identify themselves as devout Muslims and many affirm their willingness to be governed entirely by Muslim law in the realm of family relations. But they resist being told by the AIMPLB or any other male clerical organisation what that law consists of. They insist that MPL is not 'a true reflection of the intention of the Quran'. ${ }^{17}$ They consider that text to be supportive of the principle of gender equality but claim that over the centuries it has been subjected to highly 'patriarchal' readings, leading to women being deprived of many of their God-given rights. As one activist explained: 'According to most people's understanding of Islam, all of the rights belong to men, all of the duties to women! ${ }^{18}$ And another told me:

There are so many rights given to women in the Qur'an that are not found in the books of any other religion. But the religious authorities mislead people, they misuse their position... The 'ulama are an almost entirely male group. They give everything a patriarchal interpretation... interpreting the texts to suit their own interests. ${ }^{19}$

Muslim women's rights activists assert their right to read the Qur'an for themselves and interpret it in a woman-friendly way. They point to God's command that all believers read and study the Holy Book, using their own reasoning abilities to understand it, rather than relying on intermediaries:

The Qur'an clearly says that there is no clergy. So the 'ulama have no right to tell me anything. Their job is to tell women to read the Qur'an, not to tell women what the Qur'an says! ${ }^{20}$

In thus insisting on going back to the foundational Islamic text for guidance, they are reclaiming the right to ijtihād that the Sunni establishment maintains was foreclosed many centuries ago. ${ }^{21}$

These women also reject the notion, so often put forward by clerics to justify their opposition to state-initiated legal reform, that MPL is divinely given and therefore inalterable. They point out that MPL

17 Yoginder Sikand, 'Islam and Gender Justice: Interview with Suraiya Tabassum', http://www.islaminterfaith.org (December 6, 2004), accessed March 8, 2005.

${ }_{18}$ Interview, Noorjahan Begum, January 3, 2006.

${ }^{19}$ Interview, Neelofar Akhtar, November 30, 2005.

${ }^{20}$ Interview, Hasnath Mansur, November 25, 2005.

${ }^{21}$ The vast majority of Indian Muslims are Sunni, followers of the Hanafi school of law. Muslim women activists are quite diverse in terms of their sectarian affiliation, though most are also of Sunni background. But in their legal rights work they generally try to avoid identifying themselves or the issues they deal with in sectarian terms. 
was created during the colonial period. Though based on Islamic law (shari'at), it has been modified by judicial precedent and by several legislative enactments that in each case, ironically, were initiated by representatives of the 'ulama. ${ }^{22}$ So why, they ask, cannot further changes now be introduced to benefit women?

Notwithstanding their insistence on the need for legal reform, these activists are always at pains to emphasize that neither their religion nor their personal law are ultimately responsible for Indian Muslim women's oppressed condition:

Our women's problems are largely economic, caused by poverty, lack of education, lack of job opportunities. It is the media and the general public that always blames their problems on religion. ${ }^{23}$

Nevertheless, they believe that better enforcement of MPL's more woman-friendly provisions and implementation of others in ways that enhance and safeguard women's interests would go a long way toward easing the difficulties that so many confront as mothers, daughters, wives, co-wives, divorcees and widows living under Muslim law.

\section{Muslim Women's NGOs}

Muslim-led women's NGOs began to make an appearance in the late 1980s. While Muslims predominate among their staff and clientele, like other feminist NGOs they welcome women of all religions, considering it antithetical to their purpose of promoting gender equality to make sectarian distinctions among themselves or among those they serve. For some, the fact that they came into being in times of heightened communal unrest reinforces their commitment to 'communal harmony'. ${ }^{24}$ The main focus of most of these NGOs is similar: aiding and 'empowering' poor, illiterate, abandoned and otherwise marginalized women, especially victims of domestic violence, while 'raising their consciousness' about the sharp

${ }^{22}$ The laws referred to are the Wakf Validating Act 1913, Shariat Application Act 1937, Dissolution of Muslim Marriages Act 1939 (DMMA) and Muslim Women (Protection of Rights on Divorce) Act 1986 (MWA).

${ }^{23}$ Interview, Hasnath Mansur, November 25, 2005.

${ }^{24}$ This is true, for example, of Shaheen and Aman Shanti (a Christian-sponsored NGO), both working among low-income Muslim and Hindu women in the old city of Hyderabad. The Mumbai-based Women's Research and Action Group (WRAG), founded in 1993 in the aftermath of riots following the demolition of the Babri Masjid, has also been deeply involved in efforts to bring about Hindu-Muslim understanding. 
gender inequities that exist in their society and the need to strive to overcome them. Their concern with larger issues of legal reform is usually an outgrowth of these more service-oriented activities.

\section{Aawaaz-e-Niswaan}

One of the oldest, largest and most well-established Muslim-led women's NGOs is the Mumbai-based Aawaaz-e-Niswaan (Women's Voice $[\mathrm{AeN}]$ ), founded in 1987. Its current office occupies several rooms on the first floor of a seven-story walk-up building, a former Jain school in the heavily Muslim neighbourhood of Dongri. It offers literacy classes and teaches work skills to poor women, giving them the tools to both support themselves financially and deal self-confidently and effectively with the larger world around them. It also provides once-a-week marital 'counselling' sessions, run by peer counsellors who in some cases initially came to AeN seeking assistance with their own problems and then stayed on to use what they had learned to help others.

These sessions follow a pattern familiar in the world of the Indian feminist NGO mahila mandal ('women's circle'). Women gather at an appointed time, often accompanied by a close relative or neighbour and frequently carrying small children in their arms. Each new 'case' is registered in a large ledger and is called upon to tell her story, to speak out, to hold nothing back. The counsellors listen attentively and usually sympathetically, only occasionally expressing irritation when someone wanders off the point or gets overly excited or hysterical. There are frequent interruptions as the narrator's supporters contribute additional information, make corrections and offer their own opinions. Audience members, those waiting to present their own tales of woe, listen avidly, sometimes expressing sympathy or offering unsolicited suggestions. The counsellors probe for further details before conferring as a group to consider possible courses of action.

The next step is usually to summon the husband for a hearing. Should he fail to appear, a delegation may be sent to fetch him. AeN prefers, if possible, to reconcile the couple or at least broker a settlement agreeable to both parties. But the ultimate outcome of many of these disputes is a separation or divorce. Sometimes AeN calls upon a sympathetic religious functionary for help. Aisha, for example, had returned to her parents' home after suffering physical abuse from 
her husband for four years. 'I wanted to be rid of him', she told me. 'I didn't want to have his name, to be known as Rashid ki bibi ("Rashid's wife")'. Her family pleaded with him to divorce her but he refused, saying that divorce was not customary in his family. So AeN persuaded a local cleric to dissolve the marriage without his consent by faskh-enikah. ${ }^{25}$ Aisha then completed high school and found a job: 'Now that I can earn myself, I don't want to be dependent on anyone. I am very happy, living a free life!' While she could now legally remarry, she is reluctant to risk becoming trapped in another unhappy marriage.

When a husband proves recalcitrant, AeN sometimes resorts to veiled (or even not-so-veiled) threats. They may indicate to him that if he refuses to listen to reason they will assist his wife in filing for a maintenance award or will go with her to the police station to file a charge of cruelty or dowry harassment under Section 498A of the Indian Penal Code. Farzana came to AeN when her husband married a second time and moved out, leaving her and her children behind in his parents' home. A delegation from AeN went to see her husband's uncle, who owned the house in which they were living. He was sympathetic to Farzana's plight and agreed to set her up in a small house of her own. But her husband refused to contribute to her living expenses, claiming that he could not afford to support two families. So AeN took her to the 'legal centre' of Majlis, a secular women's NGO with whom they have a cooperative relationship, and with their help she obtained a maintenance order against him. ${ }^{26}$

AeN also brings women together for regularly scheduled informal gatherings, where they socialize, share personal experiences, sing uplifting songs and lend one another moral support in times of domestic crisis. In 1999, these meetings were being held in a small rented room, up some rickety stairs, above the Laxmi Beer Bar. One day 10 women had gathered, including AeN's Co-ordinator, Hasina Khan, and two other staff members. They sat sociably in a circle on the floor, discussing recent happenings in the neighbourhood and in their

${ }^{25}$ Many clerics refuse to use this procedure but others are willing to use it to accommodate women who have been abandoned or severely abused (see Sabiha Hussain, 'Male Privilege, Female Anguish: Divorce and Remarriage among Muslims in Bihar', in I. Ahmad (ed), Divorce and Remarriage among Muslims in India (New Delhi: Manohar, 2003), pp. 263-289.

${ }^{26}$ Majlis' founder is the prominent lawyer and legal scholar, Flavia Agnes (see her My Story...Our Story of Re-Building Broken Lives, $4^{\text {th }}$ edition [Mumbai: Majlis 2004] and 'Ashoka Fellow Profile-Flavia Agnes', http://www.ashoka.org/ fellows/viewprofile3.cfm?reid=128049 [1986], accessed April 4, 2006). 
lives and filling me in on the background of their own involvement with AeN. Just as one woman was winding up her tale of dowry harassment at the hands of her husband and in-laws, a youngish man burst into the room and thrust a plastic folder into Hasina's hands. It transpired that a few weeks earlier he had been summoned to AeN because his wife had come there seeking help in filing for divorce. They had been married for 4 years but, according to her, he was impotent and the marriage had not been consummated. He had denied his wife's allegations that day and now had come to deliver the results of a medical examination that he claimed would prove that he was capable of sexual intercourse. $\mathrm{He}$ was alternately deferential and belligerent. He insisted that not only was he not impotent, but that he had had sex with his wife $5^{0}$ times in the early weeks of marriage, 'not only at night but in the daytime too!' At this, all of the women in the room began to giggle; Hasina tried to maintain her composure but soon started laughing as well. He was clearly embarrassed but would not drop the subject. 'It is a matter of her word against mine. If she will place her hand on the Qur'an and swear that we never had intercourse, I will accept it'. Hasina protested: 'Here we don't do any swearing on the Qur'an. If you want to do that, do it in your own home or somewhere outside, not here'. She agreed to find a physician to interpret his medical reports and promised to contact him again. After he left they all had a good laugh at his expense and at Hasina's, for having been unable to retain a more professional demeanour during the encounter.

For special events AeN can assemble an even larger number of women. Two months prior to this meeting, members of AeN and other women's NGOs had plastered the city with posters protesting the Shiv Sena's attempts to suppress showings of the Deepa Mehta film, Fire. More recently, in July of 2005 , they mustered a 100-strong group, 'many of them wearing burqas, ... carrying roughly made cut-outs of maulanas with their faces crossed out', to shout provocative slogans against attempts by the Tablighi Jama'at in one heavily Muslim neighbourhood of the city to suppress the singing and ceremonies customarily performed by women at weddings. ${ }^{27}$

${ }^{27}$ Shashi Menon, 'Protest by Mumbai Muslim Women', http://www.mailarchive.com/sapac_chicago@yahoogroups.com/msgoı o38.html (July 29, 2005), accessed July 31, 2006. Women's customary rites have been key targets for Islamic

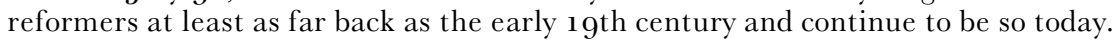




\section{Muslim Women's Networks}

A number of 'networks' or 'coalitions' of Muslim women's organisations have also come into existence in recent years. Rather than help individual women, they strive to develop a dialogue-among themselves, with the clerical establishment and within the larger community-on women's issues. To this end they hold conferences at which resolutions are passed and issued to the press and organize rallies, often in conjunction with secular women's organisations. They run 'legal awareness camps' for poor women in rural areas and urban slums and occasionally investigate and even intervene when an 'antiwoman fatwa' is issued by clerics somewhere in the country, drawing widespread public attention. ${ }^{28}$

\section{Muslim Women's Rights Network}

The most successful and longest surviving coalition and the one with the most national reach is the All-India Muslim Women's Rights Network (MWRN). It was started in 1999 in Mumbai by leaders from Women's Research and Action Group (WRAG) and AeN. Their first conference was attended by approximately $25^{\circ}$ women, including a few Hindus, from 25 different organisations. Issues of child custody, guardianship and adoption, women's rights in the marital home, compulsory registration of marriage and divorce, mahr (dower), a proposed model nikahnäma (standard marriage contract) and the need for a ban on 'instantaneous divorce' (triple talā $q$ ) were on the agenda. ${ }^{29}$ Since then they have met once or twice a year, each time in a different city. The most recent gathering, attended by 300 women and a few men, was held in November 2005 in Lucknow. On the agenda were sessions on the role of the state in protecting women's rights,

${ }^{28}$ For example, the 2005 'Imrana case', involving a rural U.P. woman allegedly raped by her father-in-law. See Sheela Reddy, 'Imrana Her Story', http:// www.outlookindia.com/full.asp?fodname $=20050718 \&$ fname $=$ Imrana $+\% 28$ F\% 29\& sid $=1$ (July 18, 2005), accessed April 17, 2006. Barbara Metcalf has analysed public responses to this event in 'Imrana: Rape, Islam and Law in India', Islamic Studies 45/3 (2006), pp. 389-412.

${ }^{29}$ Muslim Personal Law and Women: A Report of the National Conference (Mumbai: Aawaaz-e-Niswan 1999); Interview, Farhat, Yasmin and Naseem, November 30, 2005. 
'anti-woman fatwas', the impact of communal violence on Muslim women and the challenges ahead for Muslim women's activism. ${ }^{30}$

\section{Characteristics of Women Leaders}

Muslim women's rights activists are quite diverse in terms of such variables as social class, sectarian affiliation, educational background, the amount of time they commit to the cause and the degree of Islamic expertise they command. Some come from the same elite, sharif Muslim families that produced some early 2oth-century women reformers. ${ }^{31}$ However, the class origins of most of the current leadership are more modest. While almost all whom I interviewed have degrees from English-medium colleges, many were raised in lowermiddle class, non-English-speaking homes and are among the first women in their families to have been educated to this level.

Several of the activist leaders were inspired by personal hardships to devote themselves to bettering the lives of others. The father of Hasina Khan was reportedly an alcoholic, sometimes violent, who 'gambled away the family's money', forcing her mother to work as a maid and seamstress. Her brother went to work in the Gulf to help support the family but he later squandered all that they had saved from his earnings and turned to a life of crime. Hasina struggled to remain in school and work her way through college. These experiences eventually led her 'to recognise the injustices of patriarchy'. ${ }^{32}$

Sharifa Khanam is founder of an NGO called STEPS in Pudukottai, Tamil Nadu, that aids victims of domestic violence. She is currently spearheading a controversial and widely publicised campaign to build an all-woman mosque. Born 'the tenth child of a poor rural family..., [she] grew up without a father'. Due to their poverty, her family was

${ }^{30}$ Tentative Schedule: National Consultation on Muslim Women (November 21-23, 2005); Interview, Noorjehan Safia Niaz, November 28, 2005.

31 These women belonged, for the most part, to families whose male members held Islamic modernist views and were themselves engaged in social reform efforts. They were mainly concerned with promoting female education and achieving enhanced mobility for women through relaxation of the more stringent forms of female seclusion (parda). See Gail Minault, 'Women, Legal Reform, and Muslim Identity', Comparative Studies of South Asia, Africa and the Middle East 17/1 (1997), pp. 1-10 and Secluded Scholars: Women's Education and Muslim Social Reform in Colonial India (Delhi, India: Oxford University Press 1998).

32 'Ashoka Profile: Hasina Khan', http://www.ashoka.org/fellows/viewprofile3.cfm? reid $=976532$ (2000), accessed April 4, 2002. 
never able to arrange her marriage and she has remained single to this day. It is perhaps for this reason that she regards the custom of 'dowry' as one of the most serious problems facing Muslim women today. ${ }^{33}$

Rehana Sultana, Director of the Centre for Women's Studies at Hyderabad's Maulana Azad Urdu University, is another well-known spokeswoman for Muslim women's legal rights who was impelled by personal adversity to dedicate her life to empowering Muslim women. Raised in a stable, religiously observant middle-class home, she was married while still in high school. But the marriage was not a happy one and soon ended in divorce. Though her natal family gave her little financial or moral support, she was determined to finish her education; eventually she completed high school, a BA, MA, PhD, and a law degree. In addition to her university job, she runs a school for girls in a building adjoining her home in a Muslim-dominated area of the old city and devotes her weekends to a small NGO, Bazm-eShama-e-Niswān, that provides marriage counselling and legal advice to troubled women. After what she has suffered, she says, she wants to save others from a similar fate. ${ }^{34}$

\section{Legal Reform Priorities}

\section{Talāq: Male-Initiated Extra-Judicial Divorce}

Close to the top of most activists' list of priorities is the issue of maleinitiated, extra-judicial, unilateral divorce, especially the infamous instantaneous divorce by 'triple talāq'. The women do not usually speak out against extra-judicial divorce per se, in as much as it is clearly allowed by Islamic law, but they insist that if a man wishes to divorce his wife he should be required to do so in a 'phased' manner, pronouncing one talāq, then waiting for a month before uttering a second. In the meantime the two should try to reconcile their differences, with help from their respective families. Only if, after another month has passed, it is clear that their problems are irresolvable, should the man be permitted to utter the third, irrevocable tala $q .{ }^{35}$

${ }^{33}$ Vanessa Baird, 'Making Waves: Interview with Daud Sharifa Khanam', New Internationalist 367, http://newint.org/issue367/waves.htm (May 2004), accessed April 4, 2006. This practice is of Hindu origin but is widespread among Indian Muslims today.

${ }^{34}$ Interview, March 18, 1999.

${ }^{35}$ In 2002, the Supreme Court of India-in the case of Shamim Ara v. State of U.P. and Anr.- decreed that an irrevocable talā $q$ can only be given for 'a reasonable 
Indeed, when pressed on the point, most clerics ${ }^{36}$ also express disapproval of triple talāq and the AIMPLB has gone on record as 'recommending' the more gradual procedure just described. In the English version of their new model nikahnamma the husband is 'instructed' to 'avoid declaring "Talaq" thrice at a time [italics mine]'. But the Board is unwilling to go any further than this, insisting that instantaneous divorce is a 'social evil', not a 'legal' one. They say they cannot either ban or invalidate divorces effected in this manner but can only endeavour to make the faithful aware that to pronounce a 'triple talaq' is a morally undesirable act.

\section{Khul': Woman-Initiated Extra-Judicial Divorce}

Most activists would also like to make extra-judicial divorce more readily available to women. The 1939 Dissolution of Muslim Marriages Act (DMMA) provides a generous list of grounds on which a Muslim woman can file suit for divorce. But a 'court divorce' is expensive and time-consuming and a woman who resorts to it risks social disapproval. An extra-judicial khul' divorce is simply arranged and inexpensive. However, it requires the husband's consent. Activists want religious functionaries to respond more sympathetically to women's applications for khul', even when their husbands refuse to cooperate or cannot be located. Alternatively, they want the faskh-enikah option to be more liberally employed.

But male clerics do not generally favour making it easier for women to initiate divorce, reasoning that to do so would cause an unacceptable rise in the divorce rate. As the Secretary of the AIMPLB told me, 'we are in the business of preserving Muslim families, not contributing to their breakup!' He explained that women are too emotional to be given the privilege of divorcing on demand. If allowed to do so, they

cause' and must be preceded by 'an attempt of reconciliation' by relatives from each side. See http://www.supremecourtonline.com/cases/7383.html (October 1, 2002), accessed December 19, 2003. This decision notwithstanding, triple talaqs continue unabated.

${ }^{36}$ It is, of course, impossible to validly generalize about 'clerical opinion' on any particular matter of MPL. Tens of thousands of men in India are assigned-or claimthe label of 'alim (plural 'ulama). They in no way constitute a unified group, either ideologically or organizationally. They are divided by sect and within each sect into many distinct schools of thought and each has personal views on specific points of law, on which he may differ even from his closest peers. 
would begin divorcing their husbands on the slightest of pretexts; the result would be social chaos. ${ }^{37}$

\section{Mahr}

Islam obliges a man to give his bride a 'dower' (mahr) in cash or other valuables when they marry. The amount must be recorded in every marriage contract but need not be paid immediately; in India its payment is usually deferred indefinitely. Upon pronouncing an irrevocable talāq, however, the man must hand over the full amount. In theory, this provides a woman with some insurance against hasty divorce. And, should her husband divorce her anyway, the mahr serves as a nest-egg with which she can start a new life. But as there is no legal mechanism to enforce its payment, in practice few women ever receive it.

Mahr amounts are in any case often quite minimal. Women's rights activists propose that the cleric presiding over the marriage (the nikahkhwān) insist that the groom pledge more than a token amount and either pay it in full or fix it in terms of some material asset (like gold) whose value will rise with inflation. They also want clerics to speak out against the common practices whereby the husband persuades his new bride to waive her claim mahr or the in-laws convince a widow that if she claims her legal right to be paid her mahr before her deceased husband's estate is distributed among the heirs, he will suffer greatly in the afterlife. Clerics, of course, readily acknowledge that every wife is entitled to her mahr, if not during the marriage then certainly upon divorce or widowhood. Some even go so far as to declare it a sin to force a bride or widow to forego it. But few are prepared to take any firm measures to ensure that women actually benefit from this provision of the law. ${ }^{38}$

\section{Polygamy}

Restrictions on polygamy are also high on the agendas of Muslim women's rights activists. They contend that the Qur'anic injunction to

${ }^{37}$ Interview, Mohammed Abdul Rahim Qureshi, January 31, 2006.

38 Some qazis insist that, if a man wants to formally 'register' his divorce in their office and receive a signed and stamped 'divorce certificate' (talāqnāma), he must first deposit the full amount of his wife's māhr. But a man is not legally required to register his divorce and most do not. See my 'Moving the Courts: Muslim Women and Personal Law', in Z. Hasan and R. Menon (eds.), The Diversity of Muslim Women's Lives in India (New Brunswick: Rutgers University Press, 2005), pp. 18-58. 
treat multiple wives equally is clearly impossible either to comply with or to enforce; therefore, a man should be allowed to marry another wife only under very special circumstances, such as the inability of the first to bear children. ${ }^{39}$ In that case he should be required to get his current wife's permission and the nikahkhwān should be required to ascertain that he has done so before proceeding with the wedding. Again, neither the AIMPLB nor other clerical bodies have shown any inclination to discourage multiple marriages by instituting such procedures.

\section{The Model Nikahnāma}

In the 1990s, Muslim women activists began trying to make Muslims aware that the law permits a woman to specify in the marriage contract the conditions under which she is giving her assent to the match: for example, that she will be allowed to continue her education or that her husband will not take another wife during her lifetime. She may even require him to agree that, should he fail to fulfil the conditions she has set, she may dissolve the marriage herself, by a procedure called taläq-e-tafwiz (delegated divorce).$^{40}$

A Mumbai group that includes several lawyers, academics and NGO leaders has been trying since the early 1990 s to draft and disseminate a model nikahnāma that clearly presents these options. However, they have found it difficult to reach unanimity on its wording. One of the main sticking points has been whether to include a mention of talaqe-tafwiz and, if so, how. But in 1994 some of the group presented a version to the AIMPLB for its consideration. ${ }^{41}$ It tackled the problem of polygamy by including a declaration by the bridegroom as to his current marital status. If married, he is asked to affirm that his first wife is aware that he is marrying again, that he has set up a separate household for her and has made provisions for her maintenance. The

39 These same arguments were put forward in an anti-polygamy campaign conducted by the Anjuman-i Khawatin-e-Islam (All-India Muslim Ladies Conference) in 1918 (Minault, Secluded Scholars, pp. 145-146, 289-290).

${ }^{40}$ See Lucy Carroll, 'Talaq-i-Tafwid and Stipulations in a Muslim Marriage Contract: Important Means of Protecting the Position of the South Asian Muslim Wife', Modern Asian Studies 16/2 (1982), pp. 277-309. Already in the late 1930s a 'model nikahnäma' containing such a clause was promulgated-under the leadership of its Muslim president-by the non-sectarian All-India Women's Conference (Minault, Secluded Scholars, p. 299).

${ }^{41}$ Its authors were Uzma Naheed, Flavia Agnes, Nasreen Fazalbhoy and Neelofar Akhtar, assisted by Maulanas Mohammed Shoeb Koti and Abdul Waheed Wahid Fayazi. 
document also outlines some conditions under which he may later take another wife.

Not surprisingly, the AIMPLB did not embrace this document. But it did take note of the issue and after years of discussion and debate, issued its own model nikahnāma in April of 2005. ${ }^{42}$ While some activists welcomed this as a step in the right direction, most were extremely critical. ${ }^{43}$ They complained that the model contract fails to address several matters of vital importance to women's interests. For example, whereas the nikahkhwān is instructed to establish whether the couple is eligible to marry-in terms of the prohibited degrees of kinship relationship and the woman's marital status-nowhere is he instructed to verify that they are old enough, under Indian law, to do so! ${ }^{44}$ Nowhere is it mentioned that the bride may specify the conditions under which she marrying, nor is space provided on the form for her to set them down. There is also no mention of the option of khul', by which the wife can initiate dissolution of a marriage that she considers untenable. And the only mention of polygamy is contained in instructions for the nikahkhwān, who is merely told to ascertain that, if the groom already has one wife, he will follow the Qur'anic injunction to treat both wives equally. How he is to determine this is not explained.

In addition to these omissions, there are a number of clauses that activists found to be highly objectionable. For example, in the list of 'guidelines' (hidāyat) for the couple, outlining their respective marital obligations, the wife is told that it is her duty to obey her husband and never leave the house without his permission. Activists point out that such injunctions make a mockery of the concept of gender equity.

Shortly after the AIMPLB nikahnāma was unveiled, a group from AeN took part in a protest demonstration at which a young woman in a black burqa was photographed in the act of tearing it up. ${ }^{45}$ The MWRN soon released a nikahnāma of their own devising, which, they claimed,

${ }^{42}$ All India Muslim Personal Law Board, Nikahnama (New Delhi, 2005).

${ }^{43}$ Geeta Seshu, 'Nikaahnama: Time for a Gender-Just Model', http://www. humanscape.org/Humanscape/2005/June/nikah/php (June 2005), accessed April 26, 2006.

${ }^{44}$ Under the Child Marriage Restraint (Amendment) Act 1978 (GMRA), which applies to all Indians, regardless of religion, the minimum legal marriage age for women is now eighteen, for men it is twenty-one. But a large proportion of Muslim brides are younger than this.

${ }^{45}$ Anupama Katakam, 'Reluctant Reform', Frontline 22, 11 (May 21-June 3, 2005 ) http://frontlineonnet.com/fl221 1/stories/2005060300330360o.htm, accessed October 14, 2005. 
would better 'protect the rights of women in times of marriage, divorce, custody and maintenance'. ${ }^{46}$ The AIMWPLB then issued its own sharp critique of the AIMPLB document and in January 2006 announced the formation of a 30-member committee to develop 'a set of marriage laws, which ... will safeguard [women's] interests' ${ }^{47}$ by, among other things, specifying that the mahr be paid before or at the time of the nikah, prohibiting 'triple talaq' and removing the haläla rule that requires a divorced woman who wishes to remarry her former husband to first marry and be divorced by another man. ${ }^{48}$

What is rarely openly acknowledged by those campaigning for a revised model nikahnamma-though they are of course well aware of it -is that in actual practice few women ever have the chance even to examine their marriage contract, never mind add any stipulations to it. Negotiations over its terms are essentially limited to the question of how much is to be offered as mahr and they are handled entirely by the bride's father, with no input from her. Although during the wedding ceremony she is asked to consent to the marriage, she is seldom if ever given a chance to peruse the contract at that time. So even if the clauses desired by the women activists were inserted into the AIMPLB nikahnāma, there is little guarantee that any but a very few adult, highly educated and personally assertive brides would be able to lay down conditions of their own choosing. Without the active cooperation, not only of the clerical establishment but of all of the men who are arranging their daughters' marriages, a revised nikahnāma would not alter the marital ground rules for the vast majority of women.

\section{Shari'at Courts}

The AIMPLB has been trying for some time to persuade Muslims experiencing marital difficulties to approach shari'at courts (dar-ul quzat) rather than resort to the state-sponsored judiciary. Muslim

\footnotetext{
${ }^{46}$ Seshu, 'Nikaahnama'.

${ }^{47}$ Manjari Mishra, 'Muslim Women to Pen "Nikahnama"', Times of India, New Delhi (January 31 , 2006).

${ }^{48}$ In April 2006, the Supreme Court, in the case of Sher Mohammed vs. Nazma Biwi, decreed that an irrevocably divorced couple cannot be prevented from reestablishing a conjugal relationship, thus setting a precedent for future courts to refuse to enforce the halāla rule (J. Venkatesan, 'Protect fatwaseparated couple: court', The Hindu, April 22, 2006, http://www.thehindu.com/ 2006/o4/22/stories/2006042206591 100.htm [accessed May 18, 2007]).
} 
women's rights activists oppose this, as they believe that these exclusively male-run religio-legal bodies are biased against women. But they themselves are not entirely satisfied with the way the civil and criminal justice systems operate, in terms of providing solutions for women's marital and other problems. Recent moves to set up special 'women's courts' in various parts of the country reflect this attitude. However, their scepticism about the law's efficacy does not prevent Muslim women's NGOs from assisting their clients to make use of the courts when alternative measures have failed.

\section{Challenges Facing the Islamic Feminist Movement}

\section{Ideological Divisions}

Whereas all of those involved in fighting for Muslim women's rights say that their goal is to achieve gender equity under the law, there are some important differences of opinion among them. The most crucial question is whether and to what extent to go beyond the boundaries set by shari'at in seeking equal rights for women. Noorjehan Safia Niaz, a Co-Director of WRAG, told me that, since there are some areas of Islamic law that are inherently biased against women, her group advocates taking what is relevant from the Qur'an while at the same time pressuring the state to codify Muslim law anew. ${ }^{49}$ An AeN volunteer likewise told me that, while Islam gives some rights to women, there are others that are unavailable in shari'at. 'So we need to go outside it to provide women those rights as well. This is not to say that religious law should not be followed. But it is not enough'. ${ }^{50}$

The question naturally arises whether all of those who use religious arguments in arguing for gender equity are truly convinced that Islam-when interpreted 'correctly' - can provide everything that women need. The choice of an Islamic discourse can be 'both genuinean expression of ... religious convictions - and a strategic attempt to acquire legitimacy that also serves to broaden the base of support for women's rights'. ${ }^{51}$ Here Moghadam's distinction between 'Islamic' and 'Muslim' feminists is relevant: the latter are 'believing women who agree that Islamization has been detrimental... to women' and

\footnotetext{
${ }^{49}$ Interview, November 28, 2005.

${ }^{50}$ Interview, Farhat, November 30, 2005.

51 Moghadam, 'Islamic Feminism', p. 1157.
} 
approach issues of legal reform from that perspective but also 'often use familiar cultural concepts and religious phrases' in order to promote their reformist goals more effectively to a Muslim audience. ${ }^{52}$ There is reason to believe that at least some of the women whose ideas and work I have been discussing here would fall into this category.

However, there is little doubt that others sincerely believe that Islam already provides women all the rights they could possibly require. Noorjahan Begum, who runs 'women's empowerment' programs for the Hyderabad-based COVA, ${ }^{53}$ acknowledged that her organisation has some differences with AeN over this issue: 'They say we need to go beyond the shari'at, but we don't agree'. Her co-worker, Qamar, continued: 'We feel that it is enough if women get the rights that they are given by Islam'. ${ }^{54}$ It was mainly because of their discomfort with the position taken by the leadership of MWRN on this question that they and some other groups decided to withdraw from the network a few years ago, though COVA has since returned to the fold. Divergence of opinion on this point has made it somewhat difficult for MWRN to keep its membership rolls intact and to present a united front toward the male religious establishment that most regard as their principal adversary in the battle for legal reform. But thus far it has not led to a permanent cleavage. All of those involved seem to believe that more is to be gained from continuing to work together than from allowing their differences to derail the larger effort.

Whereas those who resist going outside of shari'at are naturally averse to state intervention in reform of MPL, they do not necessarily rule out supporting pro-woman legislation that impinges only indirectly upon their code of personal law. For example, none of the activists to whom I spoke oppose-as does the AIMPLB and some other clerics-the application to Muslims of the GMRA. And many have expressly called for the compulsory registration of marriages, though many clerics regard government attempts to institute such a requirement as interference in their personal law. They also argue

${ }^{52}$ Moghadam, Toward Gender Equality, p. 53.

53 COVA is not a women's organization as such, but rather 'an umbrella group of over 100 community-based organizations'. It was formed in 1994 when a number of Hindu and Muslim groups joined together to work for communal harmony and only later broadened its mandate to include issues of specific relevance to women.

${ }^{54}$ Interview, January 3, 2006. 
that it is anyway unnecessary for Muslims, since the officiating imām or $q \bar{a} z i$ already keeps a record of every marriage he performs. ${ }^{55}$

\section{Relations with the 'Ulama}

There are also differences of opinion about whether and how to work with the 'ulama on issues of personal law. Most Muslim-led women's NGOs do maintain contacts with local qazis or the imāms of nearby mosques and, as I have noted, regularly seek the cooperation of the more sympathetic among them when trying to help the women who come to them with marital or other problems. Some spend considerable time and effort trying to develop relationships with and keep open lines of communication with the local religious authorities. But they are often frustrated by these men's frequent reluctance or refusal to heed their recommendations when dealing with issues that affect women's well-being.

All of the Muslim women's networks have also at some time or other entered into dialogue with the higher clerical leadership, in particular with the AIMPLB. Those who are themselves members of this Board naturally believe in working closely with the 'ulama, exerting whatever influence they can from within, rather than opposing them from without. As one told me, 'One should be positive in one's approach, not confrontational'. ${ }^{56}$ Another pointed out that, since the masses have great respect for the 'ulama, it is counter-productive to tell women not to heed what they say. It is much better to show that one is willing to give them proper deference and work with them to the extent possible. ${ }^{57}$

The MWRN and some of the smaller coalitions, positioned well outside of the AIMPLB and not so averse to confrontation, have on different occasions invited members of the Board and other prominent clerics to discuss issues of women and the law. Though there is still a large gap between what most women activists would like to see

${ }^{55}$ In February of 2006 the Supreme Court ordered all states to institute such procedures (Smt. Seema v. Ashwani Kumar [2006] 2 SCG 86). They are already on the books in several states, though not yet actually implemented in all of them. See J. Venkatesan, 'Registration of Marriages Must: Court', The Hindu, February 15, 2006, http://www.thehindu.com/2006/02/15/stories/200602151393010o.htm, accessed April 23, 2006.

${ }^{56}$ Interview, Haseena Hashia, October 14, 2005.

${ }^{57}$ Interview, Neelofar Akhtar, November 30, 2005. 
the AIMPLB do and the steps that it has actually taken, there are clear signs that the reformist women's voices are being heard by the members of this body and are even having some impact-though hardly a dramatic one-on their decision-making. Some women are pleased by the results of their efforts to exchange ideas with the Board, while others are discouraged by what they perceive as an absence of positive results. Thus one of the leaders of WRAG is quoted as saying,

For a long time we did try to dialogue with [the AIMPLB]. But with each of their declarations, they haven't done enough. They had a golden opportunity to do so much [in their new nikahnāma]. How long can we direct our energies at them? It's like banging one's head against the wall. ${ }^{58}$

\section{Presenting a Public Image}

Activists in the movement for Muslim women's rights often find themselves in a position of having to defend themselves against both direct attacks and more subtle, insidious insinuations from the religious leadership and from members of the wider community, including members (especially men) of their own families. The activities they engage in often preclude their conforming strictly to orthodox standards of seclusion and Islamic femininity. They are also vulnerable to criticism for putting their interests as women ahead of the community's need to maintain a united front against the communal forces rampant in the society at large. Since so many Indian women's NGOs rely heavily on funding from foreign aid agencies, they are sometimes the target of suspicion on that front. And even aside from questions about the sources of their funding, they risk being accused of being 'in it only for the money' instead of genuinely concerned about the welfare of poor women.

The strength of their loyalty to the community is often questioned as well, especially if they also belong to non-sectarian women's organisations or to Muslim organisations that work closely with secular ones on controversial issues of current concern to Muslims. The same is true if they are closely associated with one of the secular political parties. In this case they may be suspected either of knowingly allowing themselves to be used by politicians (perhaps for personal gain) or

${ }^{58}$ Seshu, 'Nikaahnama'. 
of being unwittingly duped into participating in dubious activities harmful to the community. ${ }^{59}$

Women activists' Islamic credentials are also routinely questioned. Even those who succeed in presenting themselves as devout Muslims can be dismissed as lacking in scholarly qualifications when they begin to cite the Qur'an or other religious sources to support their demands for gender justice. Although growing numbers of Indian young women are being educated in women's madrasas, some even earning the title of 'alima ('female scholar'), few of these have shown an inclination to involve themselves publicly in fighting for women's rights. Activists argue that one doesn't need to be a highly-trained religious expert in order to read the Qur'an and discover for oneself that Indian Muslim women today are not being given their God-given rights. But the fact that very few of them have had a rigorous religious education makes it easy for the 'ulama to dismiss them and their ideas out of hand.

\section{To Be or Not to Be a Feminist}

Muslim women who are pressing for social and legal change in pursuit of gender equity always have to concern themselves about 'framing' the issue of women's rights in such a way that they are not 'put on the defensive and made to prove that they are not spouting alien and Western concepts'. ${ }^{60}$ Uzma Naheed, a grand-daughter of the founder of the Deoband madrasa, is one of the few prominent Muslim women's rights activists who has earned advanced Islamic qualifications. When I met her in her office, she was wearing a long-sleeved salwar-kamiz with a headscarf tied so as to completely cover her hair and shoulders. Her husband was seated at an adjoining desk but did not take any part in our conversation. When I asked about relationships between women activists and the clergy, she said that she was able to remain on good terms with the AIMPLB leadership because,

[A]lhough they know I am working for women, they know that I am not a feminist. It is because our religion has given us rights that I am doing

${ }^{59}$ For example, the fact that the Founder President of the AIMWPLB, is 'a longtime secretary of the Rashtriwadi Communist Party' has been raised by at least one of its prominent clerical critics (Puja Awasthi, 'Our Own Personal Law Board', http:/www.indiatogether.org/2006/sep/wom-aimwplb.htm, accessed May 18, 2007).

${ }^{60}$ Moghadam, Toward Gender Equality, p. $5^{1 .}$ 
this ... It is important, if we want them to listen to us, that we show that we are good Muslims. By not wearing a sari, by covering our heads and so on. ${ }^{61}$

Hasina Khan similarly used the phrase 'not strongly feminist' when explaining to me AeN's approach to raising the consciousness of their mostly poor and uneducated women clients. ${ }^{62}$ The reluctance that these and other activist women display to openly claim a 'feminist' identity-at least when campaigning for women's rights before a Muslim audience-is understandable, since the term has quite negative connotations, not only within this community but in India more generally. It calls up images of an excessively Westernized woman, unfeminine, aggressive, antagonistic toward men, immodest, sexually loose and careless of domestic and family responsibilities. Thus, despite sharing with self-identified feminists 'a theoretical perspective and a practice that criticizes social and gender inequalities, aims at women's empowerment, and seeks to transform knowledge', ${ }^{63}$ they shy away from adopting the label for themselves. ${ }^{64}$

From the other side, these women are often suspect in the eyes of their secular sisters, who tend to view them as either suffering from false consciousness or using a misplaced rhetoric as a convenient, even cynical, strategy. Even those secular feminists who recognise the difficulty of confronting an entrenched male religious establishment from within the community and are therefore prepared to give Islamic feminists credit for standing up to be counted on the issue of Muslim women's rights are often dubious about what they can actually accomplish. Yet, forced as these women are to operate within a context wherein a more radical secular feminist approach is certain to attract strong community antagonism, an Islamic feminist approach may indeed be the wisest choice.

${ }^{61}$ Interview, November 28, 2005. Though some activists do wear saris, most wear the salwar-kamiz, draping a dupatta over their chest and shoulders when indoors. Assuming this dress is not necessarily a religious statement: it is nowadays de rigeur among college-educated young women of all religions. Some activists wear a black burqa when in public, either the older style two-piece garment with attached face veil or the newer long coat with a separate square of cloth covering the head, neck and shoulders and sometimes pulled tightly across the face in such a way as to leave only the eyes visible.

${ }^{62}$ Interview, February 1 8, 1999.

63 Moghadam, 'Islamic Feminism', p. 1165 .

${ }^{64}$ For this reason some scholars question the appropriateness of using the term in their own writings (cf. Cooke, Women Claim, p. ix). 


\section{Conclusion}

I have sketched here in very broad outlines the growth and development of a nascent Islamic feminist movement in India, wherein a relatively small cohort of young to middle-aged, middle-class, collegeeducated Muslim women, spread throughout the country in various large and medium-sized cities, many of them long engaged in providing adult education and various kinds of social services to poor and otherwise marginalized women, have begun to campaign for changes in the way MPL is interpreted and applied, with the aim of achieving a greater degree of parity for the sexes under the law. To support their arguments for legal reform they refer chiefly to the authority of the Qur'an, which, they say, gives women many rights and benefits that in India today are denied them in practice.

The most immediate roots of this movement can be traced to the 1985 Supreme Court judgment in the Shah Bano case and the subsequent successful campaign by the Muslim clerical leadership to enact the MWA, making divorced Muslim women no longer eligible to sue their husbands for maintenance under the relevant provision of the Criminal Procedure Code. ${ }^{65}$ But the broader context of its emergence lies in the process of 'fragmentation of religious authority' in the contemporary globalising Muslim world that is related to such developments as the spread of mass education, the coming of new forms of media and transport and the growth of a mobile, worldwide labour market. ${ }^{66}$

With respect to issues of MPL in particular, while the Indian 'ulama continue to claim exclusive rights to interpret shari'at, the arenas in which it is now being discussed are opening up. Those who formerly followed clerical authorities unquestioningly are raising their independent voices and demanding to be heard. A variety of 'new people', including Western-educated Muslims who lack religious credentials of the traditional sort, are participating in these conversations. Robinson has argued that in India this process began with the widespread adoption of lithographic print technology by Urdu-speaking Muslims in early 19th century, a process that intensified in the early 20 th century ${ }^{67}$ For centuries, manuscripts

${ }^{65}$ See Asghar Ali Engineer (ed.), The Shah Bano Controversy (Hyderabad: Orient Longman, 1987).

${ }^{66}$ Dale F. Eickelman and James Piscatori, Muslim Politics (Princeton, NJ: Princeton University Press, 1996), pp. 68-79, $131-135$.

${ }^{67}$ Francis Robinson, 'Technology and Religious Change: Islam and the Impact of Print', Modern Asian Studies 27/1 (1993), pp. 244-251. 
of the classic texts of Islam were reproduced by hand and were consequently in scarce supply. This gave religious scholars a firm monopoly on religious knowledge. The only way to study these texts was by sitting at the feet of someone to whom the knowledge they contained had been passed down orally through a long line of earlier teachers. But now they could be reproduced, in the original language or in translation, in thousands of copies. Any literate person could read them for him or herself. There was no longer any need to rely on an intermediary to explain their meaning or to give one permission (ijäzat) to pass on what one had learned to others.

Ironically, although the 'ulama themselves exploited this technology because it enabled them to disseminate religious knowledge more widely, it ultimately eroded their authority as exclusively qualified interpreters of Islam. A wide variety of competing sectarian groups soon sprung up, each with its own religious vision. In time, newer media technologies were developed-first the radio, then television, audio and video cassettes, CD-ROM and the internet-and were enthusiastically received and utilized by such groups as well as by individual self-styled Islamic experts. In the case of the sound and visual media, the ever-expanding audience for new religious ideas included many who lack the literacy skills required to absorb them from the printed page. Even though literacy is spreading at a rapid pace throughout the Muslim world, in a country like India the number of Muslimsespecially women-who are still unable to read remains high. By whatever means they are exposed to new religious ideas, members of the modern audience are not simply passively taking them in. They are forming their own opinions, avidly discussing and debating them, and trying to bring others around to their way of thinking. Increasingly this means trying to follow-and persuade others of the importance of their following-new standards of virtuous Muslim behaviour. ${ }^{68}$

Women are becoming increasingly prominent participants in this 'new Muslim public sphere'. ${ }^{69}$ Female voices were previously virtually absent from scholarly religious discourse but today women increasingly feel in a position to develop and promote competing views on these subjects and are making themselves heard through a wide

${ }^{68}$ See Charles Hirschkind's discussion of how the wide circulation of religious cassette tapes in modern day Cairo has contributed to the creation of a new and diverse 'Islamic counterpublic' there: 'Civic Virtue and Religious Reason: An Islamic Counterpublic', Cultural Anthropology 16/1 (2001), pp. 3-34.

${ }^{69}$ Dale F. Eickelman and Jon W. Anderson, 'Defining Muslim Publics', in D. F. Eickelman and J. W. Anderson (eds.), New Media in the Muslim World: The Emerging Public Sphere (Bloomington, IN: Indiana University Press, 2003), pp. 10-1 1. 
variety of media forms, both old and new. The Indian women's rights activists about whom I have written here are part of this worldwide trend. They make ample use of the media, experiencing little difficulty in obtaining newspaper or television coverage for their activities: images of black-robed women raising a ruckus against the male clerical establishment can always be counted on to attract readers-or viewers, as the case may be. Their opinions are also regularly sought by journalists, whenever incidents occur in which Muslim women are mistreated by their menfolk, community elders or clerical authorities. Yet they are highly ambivalent about the media's role in relation to their cause, criticising it for habitually playing up such incidents in ways that reinforce existing negative stereotypes of Muslims. Here they echo the concerns of the clerical leadership, which likewise perceives the 'secular' media to be overly inclined to sensationalist reportage that helps to stir up anti-Muslim sentiments among the general public. ${ }^{70}$

\section{Muslim Women's Rights Activism and Islamic Reform}

In many ways the 'movement' I have been describing fits uneasily within current discussions of Islamic reform movements, either historically or in the contemporary Muslim world. The politics of gender have been central to reformist discourse in India from the $19^{\text {th }}$ century onwards, though its specific manifestations were varied and changed over time. Women began to be called upon to assume the role of symbolic representatives of their larger community of faith: ${ }^{71}$ this process accelerated after Independence, with pressure from both

${ }^{70}$ As Syed Jalaluddin Umari, a founding member of the AIMPLB and VicePresident of the JIH, remarked, 'The Imrana case was very bad but such things [incest and rape] also happen among Hindus. The media is biased. If something happens, one case, they make a big hullaballoo about it. One Hindu journalist said to me, 'then you should make your views known in the media'. I said 'how? The media are in your hands!' (Interview, October 25, 2005).

${ }^{71}$ Barbara D. Metcalf, 'Reading and Writing about Muslim Women in British India', Islamic Contestations: Essays on Muslims in India and Pakistan (New Delhi, India: Oxford University Press, 2004) pp. 99-1 19; Faisal Fatehali Devji, 'Gender and the Politics of Space: The Movement for Women's Reform in Muslim India, 1857-1900', South Asia 14/2 (1991), pp. 141-153. This was at work also in the nationalist discourse on women's education and reform that was directed largely at a redefinition of Hindu tradition (see Partha Chatterjee, 'The Nationalist Resolution of the Women's Question', in K. Sangari and S. Vaid [eds.], Recasting Women: Essays in Indian Colonial History [New Brunswick, NJ: Rutgers University Press, 199o], pp. 233-253). 
outside and within the Muslim fold. As Metcalf suggests, there has been

a shift in the boundaries of public and private from an ideal long held in Islamic societies: women are, ironically, now part of public life ... [and] talk about women ... fills public space. ${ }^{72}$

Contemporary Islamic reform movements are of course many and varied, both ideologically and in the specific practices that they endeavour to promote, as the other papers in this volume show. But insofar as their discourse on women is concerned, they all tend to share a preoccupation with the need for women to conform to Islamically prescribed norms (however these may be defined) of 'modest' behaviour and appearance. ${ }^{73}$ Traditional maternal and domestic roles are usually valorized as well; if, due to economic or other exigencies of modern life, women must also assume other roles, their priorities are supposed to remain with home and family. Islamist women's movements also strongly emphasize the importance of selfdisciplining the mind and body through regular prayer, the study of the Qur'an and other religious texts and the conscious emulation of ideal feminine models from the Islamic past. ${ }^{74}$

In these respects, 'Islamist' women, 'less concerned with the advancement of women's rights than with the advancement of Islamization' seem to have little in common with the Islamic feminist activists whose ideas and work I have discussed here. ${ }^{75}$ That is not to say the some of the individuals involved in women's rights activism may not also hold 'Islamist' views and be engaged in promoting these (for themselves and others) in their personal capacities or as members of religious organisations that share such an orientation. But the Muslim women's rights 'movement', per se, is not concerned with identifying

72 'Reading and Writing', p. 102.

${ }^{73}$ I do not mean to suggest that men in these movements are not also expected to adhere to norms of proper Islamic behaviour but I am specifically concerned here with the way these movements construct the ideal Muslim woman.

${ }^{74}$ See Saba Mahmood's description of a women's piety movement in Cairo (Politics of Piety: The Islamic Revival and the Feminist Subject [Princeton, NJ: Princeton University Press 2005]) and, for some South Asian examples, Barbara D. Metcalf, 'Women and Men in a Contemporary Pietist Movement: The Case of the Tablighi Jama'at', in P. Jeffery and A. Basu (eds.), Resisting the Sacred and the Secular: Women's Activism and Politicized Religion in South Asia (New Delhi, India: Kali for Women, 1999) pp. 107-122; Elora Shehabuddin, 'Beware the Bed of Fire: Gender, Democracy, and the Jama'at-i Islami', Journal of Women's History 10/4 (1999), pp. 148-1 71; and essays by Shehabuddin and by Maimuna Huq in this volume.

${ }^{75}$ Moghadam, Toward Gender Equality, p. 53. 
or enforcing particular standards of dress or deportment, teaching women how to become better Muslims or encouraging them to pray more regularly. Its leaders are indeed outspokenly critical of - and, as I have mentioned above, have at times have publicly protested againstreformers' attempts to control women's behaviour. Although I never heard it explicitly verbalized in this way, their attitude seems to reflect a conception of religion that is very far from that of the Islamists, one that sees religious faith and modes of observance as private matters, to be negotiated by each individual between herself and God.

Notwithstanding my assertion that a considerable gap exists between Muslim women's rights activists and Islamist women in India and elsewhere, there are recent indications that even the women's wing of the Indian branch of the Jama'at-e-Islami may be moving in an incipiently Islamic feminist direction on issues of Muslim marriage, family life and personal law. Whereas in 1998, 75, 00o JIH women gathered in Kerala to discuss girls education, the right to worship in mosques, abolition of dowry and 'protecting the right to live with modesty and dignity', ${ }^{76}$ at a February 2006 meeting of the same organisation in Hyderabad, attended by 30,000 people from around the country, women's legal rights were prominently highlighted and the state chief of the JIH women's wing, Nasira Khanum, was quoted as saying,

Islam advocates protection of women rights [sic] but men-dominated society hides the facts. Women themselves should know about their rights and learn to snatch them if denied! ${ }^{77}$

Whether this meeting really heralds a new direction for the JIH remains to be seen but it is certainly an encouraging sign when the leader of a religiously orthodox Islamist mass organisation of this kind essentially echoes what the leaders of so many much smaller organisations with longstanding and serious commitments to the pursuit of feminist goals, have been striving for two decades to communicate to the Muslim clerical establishment and the Muslim community at large.

${ }^{76} \mathrm{http}: / /$ ecumene.org/ACHA/5-O5-1999 (June 13, 1998), accessed June 19, 2006.

77 'Fight Injustice, Jamaat Tells Muslim Women', http://timesofindia.indiatimes. com/articleshow/msid-1411 793 curpg-1.cms (February 13, 2006), accessed April 12 , 2006; 'Women's Meet Blazes a New Trail', http:/www/thehindu.com/2006/o2/12/ stories/200602 12200605 oo.htm (February 1 2, 2006), accessed May 29, 2007. 